\title{
LANGUAGE DISORDER EXPERIENCED BY A MAN WITH ASD AS A LEADER OF CONSERVATION ORGANIZATION
}

\author{
${ }^{1}$ Khairunnisya Lubis ${ }^{D}$, ${ }^{2}$ Rahmadsyah Rangkuti $i[$ \\ Universitas Sumatera Utara ${ }^{1,2}$ \\ Corresponding email: ххххх @ххх.соm ${ }^{l}$
}

\begin{abstract}
KEYWORDS
ABSTRACT

Autism Spectrum

Discorded (ASD),

Asperger Syndrome

(AS),

Pragmatic Language

Impairment,

Psycholinguistics

This paper aims to identify the different types of language disorders that a man with autism spectrum disorder (ASD), especially Asperger Syndrome (AS), can experience. The information was in the form of phonemes, words, phrases, clauses, and sentences that he used in his everyday utterances as the leader of a local conservation group. The objective of this research is to classify different types of pragmatic impairment in AS characters and to clarify the pragmatic impairment that AS individuals face in his everyday life which conclude unresponsive, unbalanced, mismatched, lack of control and lack of playfulness based on the research problems. Academically, this analysis is intended to make substantial contributions to the fields of psycholinguistics and pragmatics. It's relevant to the psycholinguistics perspective because it's about the disability. It is a practical guide that professionals, lecturers, students, physicians, language pathologists, therapists, and readers from a variety of fields can use.
\end{abstract}

\begin{tabular}{|c|c|}
\hline $\begin{array}{c}\text { KATA } \\
\text { KUNCI }\end{array}$ & ABSTRAK \\
\hline $\begin{array}{l}\text { Autism Spectrum } \\
\text { Discorded (ASD), } \\
\text { Asperger Syndrome } \\
\text { (AS), } \\
\text { Pragmatic Language } \\
\text { Impairment, } \\
\text { Psycholinguistics }\end{array}$ & $\begin{array}{l}\text { Makalah ini bertujuan untuk mengidentifikasi berbagai jenis gangguan bahasa yang dapat dialami } \\
\text { oleh seorang pria dengan gangguan spektrum autisme (ASD), terutama Sindrom Asperger (AS). } \\
\text { Informasi tersebut berupa fonem, kata, frasa, klausa, dan kalimat yang ia gunakan dalam } \\
\text { tuturannya sehari-hari sebagai ketua kelompok konservasi lokal. Tujuan dari penelitian ini adalah } \\
\text { untuk mengklasifikasikan berbagai jenis gangguan pragmatik pada karakter AS dan untuk } \\
\text { mengklarifikasi gangguan pragmatik yang dihadapi individu AS dalam kehidupan sehari-harinya } \\
\text { yang menyimpulkan tidak responsif, tidak seimbang, tidak cocok, kurang kontrol dan kurang } \\
\text { main-main berdasarkan masalah penelitian. . Secara akademis, analisis ini dimaksudkan untuk } \\
\text { memberikan kontribusi substansial bagi bidang psikolinguistik dan pragmatik. Ini relevan dengan } \\
\text { perspektif psikolinguistik karena ini tentang disabilitas. Ini adalah panduan praktis yang dapat } \\
\text { digunakan oleh para profesional, dosen, mahasiswa, dokter, ahli patologi bahasa, terapis, dan } \\
\text { pembaca dari berbagai bidang. }\end{array}$ \\
\hline Name, N. (Y & $\begin{array}{l}\text { APA } 7^{\text {th }} \text { Citation: } \\
\text { o not write anything here. It will be filled by the editorial team after the acceptance. } \\
\text { r). Title. Wacana:Jurnal Penelitian Bahasa, Sastra dan Pengajaran, Vol (Issue), page-page } \\
\text { DOI: https://doi.org/10.33369/jwacana }\end{array}$ \\
\hline
\end{tabular}

\section{INTRODUCTION}

Dulm (2002) states that psycholinguistic is an approach adopted by linguists and clinicians to interpret both normal and disordered language phenomena. Language disorder deals with disfluency of language leading to the impairment of understanding and expressing language and it is the most prevalent type of communication impairment affecting children (Suherman, 2016). People with language disorder may have problems in their daily communication. (Field, 2003) argues that language disorder problems may be in the form of receptive, expressive, or both receptive and expressive. This case is usually experienced by the children who have mental disorder such as autism spectrum disorder (ASD). One of the types of ASD is Asperger Syndrome. 
People with AS are notorious for their inability to maintain a conversation and react appropriately or relatedly during it (Humaira, 2015). (Eysenck \& Keane, 2015) states that people with AS (a relatively mild ASD) experience pragmatic impairment in social communication although they exhibit normal language development. The pragmatics of language involves a wide skill set, including the use and understanding of non-literal language (e.g metaphor, idiom), the introduction, development and termination of a topic of conversation and the contribution of relevant, informative utterances to a conversation.

It is important to acknowledge that developmental pragmatic disorders may be found in adults and acquired pragmatic disorders can arise in children. An adult with intellectual disability related a genetic syndrome may be unable to make polite requests of a conversational partner or may fail to comprehend the indirect speech act used by others (Cumming, 2019). Frith (1991) states that people with AS have such a physical similarity to one another, but their movements are clumsy and their speech is uncommon. It means that their physical appearance is similar to that of ordinary people, but their speech patterns are troublesome. Abele \& Grenier (n.d) include examples of improper social language usage such as interrupting, speaking more loudly or quietly, and suddenly changing topics (n.d). Many people with pragmatic disorder have difficulty interacting with others, despite possessing excellent expressive language skills.

\section{Literature Review}

\subsection{Psycholinguistics}

(Aitchison, 1998) states that psycholinguistics is focused on the relationship between the human mind and the language. The study of psycholinguistics examines how we develop, perceive, and produce language. Meanwhile, (Hatch, 1983) defines that this branch of linguistics is focus on three aspects of language competence; acquisition, comprehension, and production. In short, psycholinguistics is the combination of two disciplines namely psychology and linguistics dealing with mind and language.

\subsection{Language Disorder}

Since language and thought cannot be separated and thought is reflected in language use, this condition is called language disorder. (Rao, 2007) asserts that language disorder is the impairment in using or comprehending language including some aspects namely the form, the content, and or the function in any combination. To sum up, language disorder is a specific impairment in understanding and sharing thoughts and ideas which involves the processing of linguistic information. It is often utilized as general term referring to abnormalities in mother tongue or native language.

\subsection{Types of Language Disorder}

Language disorder is divided into expressive and receptive. A person with expressive language disorder has difficulty in using language while a person with receptive language disorder has difficulty in understanding language. Besides, (Field, 2003) argues that the types of language disorder may be expressive (impaired language production), receptive (impaired language comprehension), or combination of both.

(American Psychiatric Association, 1994) assert that expressive language disorder has some linguistic features include a limited amount of speech, weak of vocabulary skill, difficulty expressing ideas, slow rate of language development, and so on. In the contrary with expressive 
language disorder, receptive language disorder has the symptom including not seeming to listen, parroting words (echolalia), etc. The last one, Mixed expressive-receptive language disorder (Tots cited in Purwaningsih, 2011), is identified as developmental delays and difficulties in the capability of comprehending spoken language and speech production. A person who has mixed receptive-expressive language disorder will have the incapability of comprehending, and or using words in context, expressing ideas, etc.

\subsection{Pragmatic Impairment}

The term pragmatic impairment has been used to refers to pragmatic disability found in aphasia, Asperger's syndrome, autism, dementia, Down's syndrome, focal brain injury, frontal lobe damage, hearing impairment, hydrocephalus, learning disability, right hemisphere damage \\and schizophrenia (Perkins, 2003) as cited by Perkins (n.d.). For example, Paul et al. (2009) explain that people with HFA (High Functioning Autism) and AS have a great problems in pragmatic such as topic management, information management and reciprocity (Ghaziuddin \& Gerstein, 1996) as cited by Paul, Landa \& Simmons (n.d.).

Topic management is giving comment related to the topic introduced by the partner of talk, and introducing the topic relevance to the shared interest. Next, information management related to the information amount and type that should be provided as needed. Then, reciprocity related to the ability to produce and respond to conversational exchanges for both verbal and non verbal.

Accordance with the pragmatic impairment experienced by people with AS, this following theory proposed by MacDonald (2004) gave empirical descriptions of the verbal communication difficulties of the autistic children. He says that the individuals' speech of AS or autistic sounds different from others mainly in the terms of the lack of ease and reciprocity in conversations.

\subsection{Autism Spectrum Disorder (ASD)}

This disorder is also generally characterized by marked and enduring impairments within the areas of communication, behaviors, and social interaction (Volkmar, 2005). This is the reason why autistic people have great problem in language production such as daily conversation because it is the area of language production. Additionally, (Rofi, 2011) asserts that the problems that may be experienced in terms of language production cover phonology, syntax, semantics, or pragmatics aspects.

\subsection{Asperger Syndrome}

Anxiety is one of the most common symptoms of AS, according to Hagland (2010), who claims that people with AS are concerned about something new or different. Autism Spectrum Disorder (ASD) is a group of developmental disorders that includes AS (ASD). Field (2004) went on to say that developmental dysfunction develops during the early stages of language learning. Meanwhile, according to the American Psychological Association (2013), AS is classified as an autism spectrum disorder (ASD), which is defined by deficiencies in social communication and interaction, as well as restricted repetitive actions, interests, and activity. Turkington \& Anan (2007) explain extensive symptoms to diagnosis AS in their encyclopedia of autism spectrum disorders. There are no apparent delays in language and cognitive development, according to reports. They typically have a normal IQ and are blessed with intellect. Nonverbal communication, social gestures, facial expressions, and eye contact are all difficult for them. Furthermore, it is clarified that people with AS want to make friends, but their social skills deficiencies make forming friendships difficult. Furthermore, their voice is often awkward.

\subsection{Language Profiles of Asperger Syndrome (AS)}

While it is well known that people with AS can speak grammatically in long sentences, their language appears to be unique in terms of both content and speech. It relates to Gillberg's (1989) claim that an AS person can produce language that is superficially perfect expressive language 
but has impaired comprehension, especially for literal and implied meanings (as cited in Kowalski, 2005).

Children with AS, according to Hagland (2010), do not normally have an apparent language delay and learn language at a regular pace. As a result, AS language development is adequate, with the exception of their difficulties in social communication skills.

As a result, people with AS tend to have strong verbal abilities (Gilberg, 2002). As a result, it demonstrates that they have issues in pragmatic environments where language is delivered ineffectively in social conversation.

According to Mesibov, Shea \& Adams (2002), professionals used two criteria to classify people with AS: first, people with AS have certain social interests, and second, they have better communication skills, which is uncommon. Importantly, the language of people with AS can be unusual in terms of both content and expression (Hagland, 2010). In summary, Kowalski (2005) has stressed that pragmatic language deficits are the most significant field of contact for people with AS.

In reality, Ghaziuddin (2005) supports the communication deficits in AS, stating that communication deficiency is one of the three major symptoms of ASD. Apart from that, the severity of disability varies, but all of the issues with social language usage are present in all situations. One example is that, in contrast to traditional turn taking in common communication, they appear to dominate their speaking with little respect for the listener (Ghaziuddin, 2005). It means they talk constantly without regard for the feelings or thoughts of the person with whom they are conversing. This way of speaking is linked to a problem with knowledge management, which leads to an unbalanced amount of conversation and a lack of sharing authority with the speaker's partner.

Furthermore, people with AS have trouble understanding that words can have different meanings, which can lead to them misinterpreting others' speech because they prefer to talk and think literally. Hagland (2010) clarified how people's propensity to take things literally causes them to misinterpret the speech of their conversation partners. Idiom, colloquial, metaphor, jokes, and other connotative expressions are examples of non-literal sentences that can be confusing because they lack of playfulness.

If someone said, "Give me your hand" an AS person may believe that someone is attempting to cut his hand and become fearful because they do not understand that the utterance means "Help". As a result, this confusion of certain events leads to the emergence of a mismatched conversation with unrelated remarks. AS patient often seem unresponsive. According to Gillberg (2002), people with AS seem to live in their own universe and do not seem to listen to other people when they speak to them. Furthermore, according to Hagland (2010), people with AS have social problems, such as ignoring what is said to them. These explanations demonstrate that they have a problem with reciprocity or communication sharing, as they often do not respond to their conversing partner.

\section{Methods}

This study relied on qualitative data. According to Miles and Huberman (Hanafiah2016), this form is used to explain data dealing with the meanings of those we are studying, and it can also be used as the foundation of a work strategy and has become a key component of social science study. The data was gathered from the utterances of an adult man with AS who works as a conservationist. This is a 34-year-old guy. Phonemes, words, phrases, clauses, and sentences were used in their utterances as the data. Direct observation of the events, interviews with those involved in the events, and documentation were used to collect data in this report.

\section{Findings and Discussion}




\subsection{Findings}

The researchers classified and described the data obtained through observation and conversation directly with an adult man with Asperger Syndrome as the workmate of the researcher. From the data that have been analyzed, there are unbalanced, mismatched, unresponsive lack of sharing control and lack of playfulness which are elaborated further.

\section{Datum 1:}

Boy: I really stress right now. That hornbill cases, car's mirror was broken made by driver, this report deadline. How if we just skip this project and take a rest? I do really stress. (Boy: Aku stress kali sekarang. Kasus paruh hornbill, kaca mobil pecah dibuat sama supir, deadline proposal. Gimana kalau kita gak usah lanjutin proposal ini dan istirahat aja? Aku benarbenar stress.)

Me: What? It's impossible because it was already $70 \%$ and the due date is tomorrow.

(Me: Hah? Gak mungkinlah, itu udah 70\% lho dan deadlinenya besok)

Boy: But, I can't resist on this anymore. I was burnt. Depressed me!

(Boy: Tapi aku udah gak tahan lagi. Sudah panas kali kepalaku. Aku stress banget)

Me: Give your hand

(Me: Siniin tangan kamu)

Boy: For what? I'm really stress right now, do not try to do something which useless or played with me. I am not in mood.

(Boy: Buat apa? Aku stress kali sekarang ini, jangan buat sesuatu yang gadak gunanya atay main-main samaku. Aku lagi gak mood).

Me: Just give me then and you will know it.

(Me: Udah siniin tangannya dan kamu bakalan tahu)

(He gave his hand)

Me: Sometimes, when we were in panicked attack, all we need just a little touch from anyone like hold our hands, hugs or just grab our shoulder.

(Me: Kadang, ketika panik menyerang, semua yang kita butuhin hanya sedikit sentuhan dari seseorang kayak genggam tangan kita, meluk atau rangkul bahu.)

(Suddenly, we across my favorite coffee shop and I unconsciously let his hands. He became so sensitive)

Boy: Is my hands too not gentle and you suddenly throw it out? That coffee shop is just as your alibi right?

(Boy: Apa tanganku kasar kali ya sampai kamu lepasin gitu aja? Kedai kopi itu cumin alibi kamu aja kan?)

(Most utterances full of stress and in high pitch)

Me: Oh my, why were you so sensitive? I just really excited for that one because I haven't got my coffee yet.

(Me: Ya Tuhan, kenapa kamu sensitive kali? Aku cumin senang lihat kedai kopinya karna aku belum ada ngopi seharian)

(Then the boy became moody again)

That moment happened when we were in the car and looked for a place for meeting and fixed our proposal deadline. Based on the conversation we can conclude that this guy has high potential for stress and really sensitive on the treatment. Even for the accidental case one. This showed one of the characteristics of Autism Syndrome Disorder, that an adult with intellectual disability related to a genetic syndrome may be unable to make a polite request of conversational partner or may fail to comprehend the indirect speech acts used by others. However, these difficulties have their origin in the limited acquisition of pragmatic language skills during the developmental period. Accordingly, the adult in this case has a developmental pragmatic 
disorder. This confusion of certain events leads to the emergence of a mismatched conversation with unrelated remarks. AS patient often seem unresponsive. Furthermore, according to Hagland (2010), people with AS have social problems, such as ignoring what is said to them. These explanations demonstrate that they have a problem with reciprocity or communication sharing, as they often do not respond to their conversing partner.

Datum 2

Boy: Please take the otter video more clearly. It is very important. The old one is really awful. (Boy: Tolong ambil video berang-berangnya lebih jelas. Ini sangat penting. Yang tadi sangat butek.)

Staff 1: The camera is bad Sir, low quality. Sorry.

(Staff 1: Kameranya memang jelek bg. Maaf.)

Boy: PLEASE TAKE THE VIDEO WITH A BETTER QUALITY. YOU HAVE TO BE SERIOUS IF IT IS ABOUT WORK BECAUSE OTTER DATA DOCUMENTATION CAN EAT THE FISH ALIVE IS VERY IMPORTANT! (Boy: SETIDAKNYA AMBIL VIDEONYA DENGAN KUALITAS YANG LEBIH BAIK. KALIAN HARUS SERIUS JIKA TENTANG PEKERJAAN KARENA DOKUMENTASI DATA BERANG-BERANG BISA MAKAN IKAN SEGAR ITU SANGAT PENTING!)

Staff 1: Yes Sir, later in the evening moment when dinner, I will take a better video. (Staff 1: Iya bang, nanti pas makan malam saya akan ambil video yang lebih baik)

In another case when this guy gave instruction to his staff, it is really hard to understand what did he means. Some staffs would ask him to clarify the meaning of what this guy said. However, this guy sometimes not successfully explained what he said. It can be seen that the conversation did not run well because his staffs looked confused whereas this man looked so fine. This conversation is classified as unbalanced include to lack of sharing control. Lack of sharing control is the situation when a person makes all the decision and direction while the others are playing a passive role. Besides, the conversation seems stuck and does not develop further. As seen on the dialogue because his acts showed that he talked too much and too detail than what the staff said. Moreover he also interrupted the staffs' work again and again without told them the further action that the staff should do. Actually, he had to give the solution than just emphasized the instruction to the staff.

Data 3:

Boy: We do not have to work too much. We have to think about our health. Do not force ourselves to work!

(Boy: Kita jangan forsir kali kerjanya. Kita harus memikirkan kesehatan kita. Jangan memaksakan diri kita untuk bekerja!)

Me: Wahh, so wise. Oh tubang.

(Me: Wahh, tumben bijak. Oh tubang.)

Boy: What is tubang?

(Boy: Apa tubang?)

Me: Googling!

(Me: Google lah)

Everyone is laughing.

The conversation above showed that that guy did not understand sarcasm. He did not care that the other people are laughing because of his eccentricity. It happens because this guy lacks of playfulness. It can be indicated in the conversation when the guy does not feel offended to the researcher that has teased him and has made fun of him. He seriously 
explains about how the staff should work while the other feels that he is funny because of 'tubang' word. But once again, it does not mean that he is stupid, he is simply expressing his ideas about work behavior and he did not feel that there is something wrong with him. In addition, his curiosity leads him to get better understanding about slang words deeply.

\subsection{Discussion}

Following the analysis of the results, a detailed discussion of the findings is needed. It seeks to answer two research questions: first, what types of pragmatic disability AS characters experience, and second, how AS characters experience pragmatic impairment. MacDonald's hypothesis (2004) about the verbal language profiles of children with autism was included in both questions. The first question looked at the different types of pragmatic impairments that are linked to social conversation disorder, while the second looked at the differences between AS communication and general communication skills. Then, in the section below, certain study problems are addressed in greater depth.

\subsubsection{Kinds of Pragmatic Impairment occur in AS character.}

Even though children and adults with AS have excellent expressive language skills, pragmatics is the major challenge they face, according to Gillberg (2002). They can understand the meaning of each word, possess excellent grammar skills, and be able to create syntactically sound sentences, but they often misuse the words in inappropriate situations. As a result of this problem, they often have difficulty communicating with others in an engaging manner. Unbalanced, mismatched, unresponsive, lack of sharing control and lack of playfulness are the five profiles suggested by MacDonald (2004) for verbal autistic children. These profiles reveal that children with autism or language disorders, such as AS, have communication difficulties that cause them to appear and sound different from their peers.

In the conversation between the guy and his talk partners, all of the language profiles related to deficits in social pragmatic use of language proposed by MacDonald (2004) were found. However, the occurrence of the inappropriate expressions or responses are not always presenting in all entire contexts of conversation.

There are some data are classified as unresponsive type. Unresponsive is the situation when a speaker in the conversation is ignored by the partner and the partner does not give respond to what speaker said. Datum 1 and 2 are considered as unresponsive. In line with those illustration, Hagland (2010) states that people with AS have social difficulties, for example they often ignore what has been said to them and it makes them apparent to be rude person who unconsidered to others.

Next, unbalanced is the situation when a person talks too much than the partner of talk, so the partner of talk waits much time for the other and talks with little chance. Datum 2 considered as unbalanced conversation. According to Ghaziuddin and Gerstein (1996) as cited in Ghaziuddin (2005) the conversation with people with AS lacks of reciprocal relationship which makes it tends to be dominated by those with AS because they have no regard to the listener and the speech is jumbled. Therefore, it makes their speech often sounds awkward.

Mismatched is the situation when two people seem do not talk the same thing. Datum 1, 2 and 3 are mismatched. MacDonald (2004) reminds the reader that many autistic spectrum 
children have different minds to people in common. In accordance with that condition, Hagland (2010) explains that people with AS are having difficulty in understanding other people point of view, social rules, non- verbal cues, and emotional signals which happens because they lack of "theory of minds" that makes them difficult to understand or guess what people around them likely think or feel. Moreover, Hagland (2010) emphasizes that people with AS see the world only from their own perspective, so they cannot imagine what other people feel. It means that people with AS just think from their own perspectives and fail to understand another person's point of view which make them easily to say whatever comes to their mind.

Another term which is almost similar to unbalanced is lack of sharing control. Lack of sharing control is the situation when a person makes all the decision and direction while the others are playing a passive role like in datum 2 . Besides, the conversation seems stuck and does not develop further.

Furthermore, lack of playfulness is the situation when the conversation tends to be tense than relax because seldom reflects humor. It might happen because a speaker cannot express and understand the implied meaning of certain sentences including humor. Datum 1 and 3 considered as lack of playfulness. Those with AS often take everything literally (Hagland, 2010). In another words, Gillberg (2002) states that people with AS have problems with metaphorical language or any language that has not been explained explicitly to them. Therefore, it means that they just understand the real meaning or denotation than the figurative meaning or connotation. It is difficult for them to understand figures of speech such as: jokes, colloquial expressions, and other words. Those metaphorical words often make them confuse a lot.

Lack of playfulness has the correlation with mismatched. Both of them make unsuccessful conversation because of the misunderstanding to the statement made by the partner of talk. Consequently, the intended meaning of the partner of talk cannot be understood well. So, the information between two speakers are not shared successfully. This condition is explained by Paul, Landa and Simmons (n.d.) that speakers with ASD has pragmatic problems which related to presupposition, the ability to provide relevant answer containing information as needed by the listener. As a consequence, this problem leads those with ASD to say inappropriate answers toward the partner of talk's statements or questions. Overall, based on the results of analysis, the frequent type of pragmatic impairment in social communication which mostly appeared is unresponsive.

\subsubsection{The pragmatic impairment of an individual with AS compares to communication skills of people in common.}

As we know, the important aspect in conversation is a joint action. Carroll (2008) explains that a joint action means that the speakers acting in coordination one another. In the other word the conversation should be balanced, match, responsive, sharing control, and sometimes playfulness. Therefore, both speakers should actively build a nice conversation by supporting each other in order to make the conversation works smoothly. However, most people with AS lack of those social skills in conversation. Thus, the explanation below explores about the social language use laxity or pragmatic impairment compares with the communication skills of people in common. 
In communication speakers should regard one another to make the interaction communicative and flow smoothly, because basically everyone does not want to be ignored by somebody. Bostom (1990) \& Steil (1991) as cited in Molen \& Hoogland (2005) states that to have a good structure and to let the partner know that he is being listened to are important in a conversation. Unfortunately, sometimes people with AS ignores another person while talking as it is shown in datum 1. Sometimes, their unresponsive attitude like that shown in the datum appears rude for the partner of talk. In the other case their ignorance is like children with common development.

\section{Conclusion and Suggestion 5.1 Conclusion}

From this study, the following conclusions related to the findings are drawn based on the statement of the problems, the results of the analysis, and the discussion of the findings. The results of the study show that all of the kinds of pragmatic impairment occur in the conversation between the guy as leader of conservation group and his staffs. Moreover, it should be noted that the impairment does not exist in every context in conversation because there is some expressions and responses which utter well and can be accepted by the listener. In brief, the pragmatic capability of adult with AS are not fully developed well yet, because their ability in using language which is suitable in the social context still impaired. Moreover, compared to the communication skills of the people in common, their expressions and responses of adult with AS are sometimes like children with common development or the way they speak is not similar to adult with common development.

\subsection{Suggestion}

Based on the findings of this study, the suggestions are offered for further research. Since we know that people with AS have laxity in pragmatic area which makes their conversation seems odd or unusual, the listener should understand that being different does not mean incompetent at the intelligence. In light of the findings of this study, the researcher also offers some suggestions for the next researchers. First, it is better for them to do field research which exposes interesting language phenomenon of people with AS in a real conversation. Second, it is important to concern not only on the drawbacks of people with AS but also the way to improve the language abilities and social skills of people with AS so that they can have a better skill to communicate interactively with others people for their better life in future.

\section{REFERENCES}

Abele, E. \& Grenier, D. (2005). The language of social communication: running pragmatics groups in schools and Clinical Settings. In Baker, L. J., \& Welkowitz, L. A. (Eds.). Asperger's syndrome: intervening in schools, clinics, and communities (pp. 217-242). New Jersey: Lawrence Erlbaum Associates.

APA (American Psychiatric Association). (2013). Diagnostic and statistical manual of mental disorder ( $5^{\text {th }}$ ed.). Arlington: American Psychiatric Publishing.

Benner, G. J., \& Nelson, J. R. (n.d.). Emotional disturbance and communication. In Cummings, L. (Ed.). The Cambridge Handbook of Communication Disorders. New York: Cambridge University Press. 
Bowler, D. M. (2007). Autism spectrum disorder: psychological theory and research. London: John Wiley \& Sons, Ltd.

Carroll, D. W. (2008). Psychology of language ( $5^{\text {th }}$ ed.). Belmont: Thomson Wadsworth.

Cotugno, A. J. (2009). Group intervention for children with autism spectrum disorders: a focus on social competency and social skills. London: Jessica Kingsley Publishers.

Dewi, K. (2012, April 15). Asperger Syndrome. Retrieved from www.anakku.net/asperger-syndrome.html

Dimitracopoulou, I. (1990). Conversational competence and social development. New York: Cambridge University Press.

Eysenck M. W., \& Keane M. T. (2015). Cognitive psychology: a student handbook $\left(7^{\text {th }}\right.$ ed.). New York: Psychology Press.

Field, J. (2004). Psycholinguistics: the key concepts. New York: Routledge. Frith, U. (1991). Autism and asperger syndrome. Cambridge: Cambridge

Ghaziuddin, M. (2005). Mental health aspects of autism and asperger syndrome.

Gillberg, C. (2002). A guide to asperger syndrome. Cambridge: Cambridge University Press.

Hagland, C. (2010). Getting to grips with asperger syndrome: understanding adults on the autism spectrum. London: Jessica Kingsley Publishers.

Hargie, O \& Dickson, D. (2004). Skilled interpersonal communication : research, theory, and practice $\left(4^{\text {th }}\right.$ ed.). London: Routledge

Johnson, B.A. (1996). Language disorders in children: and introductory clinical perspective. New York: Delmar Publishers.

Kowalski, T. P. (2005). Assessing communication skills in asperger's syndrome: an introduction to the conversational effectiveness profile. Florida Journal of Communication Disorders, 22. (pp. 29-34).

Landa. (n.d.). Social language use in asperger syndrome and high-functioning autism. In Klin, A., Volkmar, F. R., \& Sparrow, S. S. (Eds.). Asperger Syndrome (pp. 125-155). New York: Guilford Press.

Lerner, J. W., \& Johns, B. (2015). Learning Disabilities and Related Disabilities: Strategies for Success $\left(13^{\text {th }}\right.$ ed). Stamford: Cengange Learning.

Lindblad, T. (n.d.). Communication and asperger syndrome: the speech language pathologist's role. In Stoddart, K. P. (Ed.). Children, youth and adults with asperger syndrome integrating multiple perspectives (pp. 125-139).

MacDonald, J. D. (2004). Communicating partners : 30 years of building responsive relationships with late-talking children including autism, Asperger's syndrome (ASD), Down syndrome, and typical development developmental guides for professionals and parents. Philadelphia: Jessica Kingsley Publishers.

Mesibov, G. B., Shea, V., \& Adams, L. W. (2002). Understanding asperger syndrome and high functioning autism. New York: Kluwer Academic Publishers. 
Molen, H. T. V., \& Hoogland, Y. H. G. (2005). Communication in organizations: basic skills and conversational models. New York: Psychology Press Taylor \& Francis Group

Painter, K. K. (2006). Social skills groups for children and adolescents with asperger's syndrome: a step-by-step program. London: Jessica Kingsley Publishers.

Paul, R., Landa, R., \& Simmons, E. (n.d.). Communication in Asperger syndrome. In McPartland, J. C., Klin, A. and Volkmar F. R (Eds.). Asperger syndrome assessing and threating high-functioning autism spectrum disorders $\left(2^{\text {nd }}\right.$, pp. 103-139). New York: The Guilford Press.

Perkins, M. R. (n.d.). Pragmatic impairment as an emergent phenomenon. In Ball, M. J., Perkins, M. R., Müller, N., \& Howard, S. (Eds.). The handbook of clinical linguistics (pp. 79-91). Oxford: Blackwell Publishing. . (2007). Pragmatic impairment. New York: Cambridge University Press.

Ray, W. J. (2015). Abnormal psychology: neuroscience perspectives on human behavior and experience. California: Sage Publication, Inc.

Rizvi, M. A., \& Kapoor, R. (2010). Communication for retail professionals. New Delhi: Tata McGraw Hill.

Shipley, K. G., \& McAfee, J. G. (1992). Communicative disorders: an assessment manual. Springer Science+ Business Media Oordrecht.

Shore, S. M. \& Rastelli, L. G. (2006). Understanding autism for dummies.

Soile, L. (2007). The use of context in pragmatic language comprehension in normally developing children with asperger syndrome/ high functioning autism. Disertation thesis. Oulu: Faculty of Humanities, Department of Finnish, Information Studies and Logopedics, University of Oulu.

Turkington, C. and Anan, R. (2007). The encyclopedia of autism spectrum disorders. New York: Facts on File.

Utomo, A. P. S. (2011). A psycholinguistics study on receptive language disorder of an asperger syndrome man in adam movie. Unpublished Thesis. Malang: English Letters and Language Department Maulana Malik Ibrahim State Islamic University of Malang.

Wulan, F. (2010). A psycholinguistics analysis of character with asperger syndrome in the movie my name is khan. Unpublished Thesis. Malang: English Letters and Language Department Maulana Malik Ibrahim State Islamic University of Malang. 